\title{
Sistem Pendukung Keputusan Pemilihan Topik Skripsi Program Studi Teknik Informatika Menggunakan Simple Additive Weighting (SAW)
}

\author{
Damayanti Hulu $^{1 *}$, R. Mahdalena Simanjorang ${ }^{2}$ \\ ${ }^{1,2}$ STMIK Pelita Nusantara \\ Jl. Iskandar Muda No. 1 Medan 20154 Indonesia \\ Corresponding author's e-mail: damayantihulu@gmail.com
}

\begin{abstract}
Abstrak - Jurusan Teknik Informatika di STMIK Pelita Nusantara merupakan salah satu jurusan pada perguruan Tinggi Swasta fokus pada keilmuan bidang teknologi informasi. Problem skripsi pada jurusan ini juga harus diselesaikan dengan segera, salah satunya dengan sistem yang memanfaatkan teknologi informasi. Kondisi mahasiswa kesulitan untuk menentukan pilihan topik skripsi untuk disusun sebagai persyaratan lulus. Kriteria yang digunakan ada 7 yaitu : Nilai Akademik, Histories Project, keaktifan Penelitian, Pelatihan, Minat, Nilai Praktek dan Tempat Penelitian. Data penelitian diperoleh dari STMIK Pelita Nusantara diterapkan metode SAW (Simple Additive Weighting) menggunakan Visual Basic Net 2010 dengan Database Mysql. Dari perangkingan menunjukkan hasil yang tertinggi adalah alternatif A1 dimana dalam contoh ini topik skripsi yang di pilih adalah Sistem Pakar.
\end{abstract}

Kata kunci: topik skripsi, SPK, nilai kriteria, metode SAW

Abstract - The Department of Informatics at STMIK Pelita Nusantara is one of the departments at private universities that focuses on the science of information technology. Thesis problems in this department must also be resolved immediately, one of which is a system that utilizes information technology. It is difficult for students to determine the choice of thesis topic to be prepared as a graduation requirement. There are 7 criteria used, namely: Academic Value, Historical Project, Research Activeness, Training, Interests, Value of Practice and Research Place. Research data obtained from STMIK Pelita Nusantara applied the SAW (Simple Additive Weighting) method using Visual Basic Net 2010 with Mysql Database. From the ranking it shows that the highest result is alternative A1 where in this example the thesis topic chosen is Expert System.

Keywords: thesis topic, DSS, criteria value, SAW method

\section{Pendahuluan}

Dalam proses perkuliahan yang tidak singkat, mahasiswa bingung untuk menentukan topik bahasan yang akan digunakan sebagai skripsi. Banyaknya matakuliah yang telah ditempuh justru membuat mahasiswa semakin sulit menentukan pilihan pada satu bidang yang akan difokuskan sebagai skripsi. Apalagi jika skripsi bidang teknologi pembahasannya harus mengikuti perkembangan terkini. Hak ini justru akan membuat mahasiswa semakin sulit menentukan pilihan. Walaupun sebenarnya kesulitan tersebut bisa diatasi dengan penilaian kemampuan diri sendiri terhadap ilmu-ilmu yang telat diberikan pada proses perkuliahan. Minat dan bakat juga dapat menjadi salah satu pertimbangan dalam pengambilan judul skripsi.

Metode SAW (Simple Additive Weighting) dikenal dengan istilah metode penjumlahan terbobot. Konsep dasar metode SAW adalah mencari penjumlahan terbobot dari rating kinerja pada setiap alternative pada semua atribut. Metode SAW (Simple Additive Weighting) ini efisien karena waktu yang dibutuhkan dalam perhitungan lebih singkat [1]. Metode SAW membutuhkan proses normalisasi matriks keputusan (X) kesuatu skala yang dapat diperbandingkan dengan semua rating alternative yang ada.penelitian sebelumnya secara lugas dan komprehensif. Penelitian Sistem Pendukung Keputusan untuk menentukan judul skripsi Jurusan Tekhnik Informatika Komputer dengan menggunakan metode Simple Additive Weighting (SAW) menggunakan metode SAW dengan kriteria Pengguna Judul Skripsi, Jenis Skripsi, Refrensi, Tingkat Kesulitan, dan Bidang Kemampuan [2]. Penelitian Sistem Pendukung Keputusan Pemilihan Topik Skripsi Program Studi Teknik Informatika Menggunakan Metode Simple Additive Weighting menjelaskan Metode pengembangan sistem yang digunakan dalam adalah metode Waterfall sebagai model yang membangun suatu perangkat lunak berdasarkan Daur Hidup Perangkat Lunak (Sistem Development Life Cycle/SDLC) dengan struktur mulai dari perencanaan, analisis, desain, implementasi, dan pengujian [3].

Penelitian Rancang Bangun Implementasi Sistem Pendukung Keputusan Pemilihan Siswa Berprestasi menggunakan Metode SAW pada SMK Al Hidayah 1 Jakarta menjelaskan Sistem Pendukung Keputusan (SPK) atau Decision Support Sistem (DSS) adalah sebuah sistem yang mampu memberikan kemampuan pemecahan masalah maupun kemampuan pengkomunikasian untuk masalah dengan kondisi semi terstruktur dan tak terstruktur [4]. Sistem ini digunakan untuk membantu pengambilan keputusan dalam situasi semi 
terstruktur dan situasi yang tidak terstruktur [5].

\section{Tinjauan Pustaka}

2.1. Sistem Pendukung Keputusan (SPK)

Sistem Pendukung Keputusan (Decision Support Sistem) adalah suatu sistem yang memiliki kemampuan dalam pemecahan masalah/komunikasi untuk kondisi masalah yang terstruktur maupun tidak terstruktur yang mempunyai peran dalam membantu pemecahan masalah dan tidak satupun yang mengetahui bagaimana keputusan yang seharusnya dibuat [6]. Sistem pendukung keputusan adalah sistem penghasil informasi yang ditujukan pada suatu masalah tertentu yang harus dipecahkan oleh manager dan dapat membantu manager dalam pengambilan keputusan [7][8].

\subsection{Metode Simple Additive Weighting (SAW)}

Metode Simple Additive Weighting (SAW) merupakan salah satu metode penyelesaian masalah yang sering juga dikenal dengan istilah metode penjumlahan berbobot. Konsep dasar metode Simple Additive Weighting (SAW) adalah mencari penjumlahan terbobot dari rating kinerja pada setiap alternatif dari semua atribut [9]. Metode Simple Additive Weighting (SAW) disarankan untuk menyelesaikan masalah penyeleksian dalam sistem pengambilan keputusan multi proses [10]. Konsep dasar metode Simple Additive Weighting (SAW) adalah mencari penjumlahan terbobot dan rating kinerja pada setiap alternatif pada semua atribut yang ada. Langkah-langkah penyelesaian suatu masalah menggunakan metode SAW yaitu [11] [12]:

1. Menentukan kriteria-kriteria yang akan dijadikan acuan dalam pengambilan keputusan, yaitu Ci.

2. Menentukan rating kecocokan setiap alternatif pada setiap atribut.

3. Membuat matrik keputusan berdasarkan kriteria (Ci), kemudian melakukan normalisasi matrik berdasarkan persamaan yang disesuaikan dengan jenis atribut (atribut keuntungan ataupun atribut biaya) sehingga diperoleh matriks ternormalisasi.

4. Hasil akhir diperoleh dari proses perangkingan yaitu penjumlahan dari perkalian matrik ternormalisasi $\mathrm{R}$ dengan vektor bobot sehingga diperoleh nilai terbesar yang dipilih sebagai alternatif terbaik (Ai) sebagai solusi.

Metode Simple Additive Weighting (SAW) membutuhkan proses normalisasi matriks keputusan (x) kesuatu skala yang dapat di perbandingkan dengan semua rating alternatif yang ada.

\section{Metode Penelitian}

Uraian kerangka kerja penelitian:

a. Analisa Masalah

Pada tahap analisa masalah yaitu melakukan analisa terhadap data yang diperoleh dari penelitian yang telah dilakukan pada tahap pengumpulan data untuk mengetahui permasalahan yang terjadi.

b. Pengumpulan data

Pada tahap ini dilakukan proses pengumpulan data dengan metode wawancara dan observasi untuk melakukan pengamatan dan analisa terhadap proses pemilihan konsentrasi skripsi Program Studi Teknik Informatika sehingga mendapatkan data dan informasi yang dibutuhkan.

c. Proses Metode SAW

Pada tahap ini melakukan penyelesaian contoh permasalahan dalam pemilihan topik skripsi yang dihadapi mahasiswa-mahasiswi dengan menerapkan metode Simple Additive Weighting (SAW).

d. Perancangan/Pembangunan Sistem

Pada tahap ini melakukan perancangan sistem yang akan dibangun pada penelitian ini. Rancangan sistem terdiri dari rancangan logika sistem dan interface sistem.

e. Implementasi Sistem

Implementasi sistem yaitu tahap yang dilakukan oleh sebagai wujud nyata data sistem yang telah dibangun untuk menyelesaikan permasalahan dalam proses pemilihan konsentrasi sikripsi Program Studi Teknik Informatika secara nyata.

\section{Hasil dan Pembahasan}

Analisis data untuk pemilihan topik skripsi program studi teknik informatika pada penelitian, data alternatif yaitu data peserta yang termasuk kedalam kandidat yang akan dipilih pada topik skripsi program studi teknik informatika yaitu Sistem Pakar (A1), Jaringan Syaraf Tiruan (A2), Logika Fuzzy (A3), Data Mining (A4), Sistem Pendukung Keputusan (A5), Rekayasa Perangkat Lunak (A6), Model Simulasi (A7), Kecerdasan Buatan (A8), Pengolahan Citra (A9), Keamanan Komputer (A10).

Data kriteria yaitu data yang digunakan untuk pengambilan keputusan dalam proses pemilihan topik skripsi 
program studi teknik informatika yaitu Nilai Akademik (C1), Histories Project (C2), Keaktifan Penelitian (C3), Pelatihan (C4), Minat (C5), Nilai Praktek (C6), Tempat Penelitian (C7).

Rating kecocokan setiap alternatif dengan setiap kriteria. Dalam penentuan rating kecocokan maka nilai dari masing-masing criteria dimasukkan kedalam tabel rating kecocokan yang telah disesuaikan dengan nilai dari tabel kriteria. Penentuan nilai yang telah diperoleh pada masing-masing alternatif terhadap kriteria selanjutnya akan dianalisis dalam bentuk tabel rating kecocokan, Tabel 1. Matriks keputusan berdasarkan kriteria (Ci).

\begin{tabular}{|c|c|c|c|c|c|c|}
\hline \multicolumn{7}{|c|}{ Tabel 1. Rating Kecocokan } \\
\hline $\mathrm{C} 1$ & $\mathrm{C} 2$ & C3 & C4 & C5 & C6 & C7 \\
\hline $\begin{array}{l}0,7 \\
5\end{array}$ & 1 & 1 & $\begin{array}{l}0,7 \\
5\end{array}$ & 0,5 & $\begin{array}{l}0,7 \\
5\end{array}$ & 0,5 \\
\hline $\begin{array}{l}0,7 \\
5\end{array}$ & 0,5 & 1 & $\begin{array}{l}0,7 \\
5\end{array}$ & 0,5 & 1 & 0,5 \\
\hline $\begin{array}{l}0,7 \\
5\end{array}$ & 1 & $\begin{array}{l}0,7 \\
5\end{array}$ & $\begin{array}{l}0,7 \\
5\end{array}$ & 0,5 & 0,5 & 0,5 \\
\hline 0,5 & 0,5 & 0,5 & $\begin{array}{l}0,2 \\
5\end{array}$ & $\begin{array}{l}0,2 \\
5\end{array}$ & 0,5 & $\begin{array}{l}0,7 \\
5\end{array}$ \\
\hline 1 & 0,5 & $\begin{array}{l}0,7 \\
5\end{array}$ & 0,5 & $\begin{array}{l}0,7 \\
5\end{array}$ & $\begin{array}{l}0,2 \\
5 \\
\end{array}$ & $\begin{array}{l}0,7 \\
5\end{array}$ \\
\hline $\begin{array}{l}0,2 \\
5 \\
\end{array}$ & 0,5 & $\begin{array}{l}0.2 \\
5 \\
\end{array}$ & $\begin{array}{l}0,7 \\
5 \\
\end{array}$ & $\begin{array}{l}0,7 \\
5 \\
\end{array}$ & $\begin{array}{l}0,2 \\
5 \\
\end{array}$ & $\begin{array}{l}0,2 \\
5\end{array}$ \\
\hline $\begin{array}{l}0,2 \\
5 \\
\end{array}$ & $\begin{array}{l}0,2 \\
5 \\
\end{array}$ & 1 & $\begin{array}{l}0,7 \\
5 \\
\end{array}$ & 0,5 & 1 & 0,5 \\
\hline $\begin{array}{l}0,7 \\
5 \\
\end{array}$ & 1 & 0,5 & 0,5 & 0,5 & 0,5 & 0,5 \\
\hline 0,5 & 0,5 & 0,5 & $\begin{array}{l}0,2 \\
5 \\
\end{array}$ & $\begin{array}{l}0,2 \\
5 \\
\end{array}$ & 0,5 & 0,5 \\
\hline 1 & 0,5 & $\begin{array}{l}0,7 \\
5 \\
\end{array}$ & 1 & $\begin{array}{l}0,7 \\
5 \\
\end{array}$ & 1 & $\begin{array}{l}0,7 \\
5 \\
\end{array}$ \\
\hline
\end{tabular}

\begin{tabular}{|c|c|c|c|c|c|c|c|}
\hline \multicolumn{8}{|c|}{ Tabel 2. Matrik Rating Kecocokan } \\
\hline \multirow{2}{*}{$\begin{array}{l}\text { Alternat } \\
\text { if }\end{array}$} & \multicolumn{7}{|c|}{ Kriteria } \\
\hline & $\mathrm{C} 1$ & $\mathrm{C} 2$ & C3 & $\mathrm{C} 4$ & $\mathrm{C} 5$ & C6 & C7 \\
\hline A1 & $\begin{array}{l}0,7 \\
5\end{array}$ & 1 & 1 & $\begin{array}{l}0,7 \\
5\end{array}$ & 0,5 & $\begin{array}{l}0,7 \\
5\end{array}$ & 0,5 \\
\hline $\mathrm{A} 2$ & $\begin{array}{l}0,7 \\
5\end{array}$ & 0,5 & 1 & $\begin{array}{l}0,7 \\
5\end{array}$ & 0,5 & 1 & 0,5 \\
\hline A3 & $\begin{array}{l}0,7 \\
5\end{array}$ & 1 & $\begin{array}{l}0,7 \\
5\end{array}$ & $\begin{array}{l}0,7 \\
5\end{array}$ & 0,5 & 0,5 & 0,5 \\
\hline A4 & 0,5 & 0,5 & 0,5 & $\begin{array}{l}0,2 \\
5\end{array}$ & $\begin{array}{l}0,2 \\
5\end{array}$ & 0,5 & $\begin{array}{l}0,7 \\
5\end{array}$ \\
\hline A5 & 1 & 0,5 & $\begin{array}{l}0,7 \\
5\end{array}$ & 0,5 & $\begin{array}{l}0,7 \\
5\end{array}$ & $\begin{array}{l}0,2 \\
5\end{array}$ & $\begin{array}{l}0,7 \\
5\end{array}$ \\
\hline A6 & $\begin{array}{l}0,2 \\
5\end{array}$ & 0,5 & $\begin{array}{l}0.2 \\
5\end{array}$ & $\begin{array}{l}0,7 \\
5\end{array}$ & $\begin{array}{l}0,7 \\
5\end{array}$ & $\begin{array}{l}0,2 \\
5\end{array}$ & $\begin{array}{l}0,2 \\
5\end{array}$ \\
\hline A7 & $\begin{array}{l}0,2 \\
5\end{array}$ & $\begin{array}{l}0,2 \\
5\end{array}$ & 1 & $\begin{array}{l}0,7 \\
5\end{array}$ & 0,5 & 1 & 0,5 \\
\hline A8 & $\begin{array}{l}0,7 \\
5\end{array}$ & 1 & 0,5 & 0,5 & 0,5 & 0,5 & 0,5 \\
\hline A9 & 0,5 & 0,5 & 0,5 & $\begin{array}{l}0,2 \\
5\end{array}$ & $\begin{array}{l}0,2 \\
5\end{array}$ & 0,5 & 0,5 \\
\hline A10 & 1 & 0,5 & $\begin{array}{l}0,7 \\
5\end{array}$ & 1 & $\begin{array}{l}0,7 \\
5\end{array}$ & 1 & $\begin{array}{l}0,7 \\
5\end{array}$ \\
\hline
\end{tabular}

kriteria ditentukan nilai Bobot (W) Nilai 1 = Sangat Baik (SB) Nilai $0.75=$ Baik (B) Nilai 0.5 = Cukup Baik (CB) Nilai 0.25 = Kurang Baik (KB) Nilai $0=$ Sangat Kurang Baik (SKB). Perhitungan normalisasi untuk mendapatkan matriks nilai ternormalisasi (R), dengan ketentuan untuk normalisai nilai, jika faktor/attribut kriteria bertipe cost maka digunakan rumusan $\mathrm{Rij}=(\min \{\mathrm{Xij}\} / \mathrm{Xij})$ sedangkan jika faktor/attribut kriteria bertipe benefit maka digunakan rumusanRij $=(\mathrm{Xij} / \max \{\mathrm{Xij}\})$. Nilai preferensi untuk setiap alternative diperoleh dengan menjumlahan hasil perkalian antara rating kinerja ternormalisasi dengan bobot setiap kriteria. Hasil perhitungan nilai Vi yang lebih besar mengindentifikasi bahwa alternatif Ai merupakan alternatif terbaik. $\mathrm{W}=[0.20 ; 0.20 ; 0.20 ; 0.15 ; 0.10 ; 0.10 ; 0.05]$

$\mathrm{V} 1=(0.20 \times 0.75)+(0.20 \times 1)+(0.20 \times 1)+(0.15 \times 0.33)+(0.10 \times 0.66)+(0.10 \times 0.75)+(0.05 \times 0.66)=0.775$

$\mathrm{V} 2=(0.20 \times 0.75)+(0.20 \times 0.5)+(0.20 \times 1)+(0.15 \times 0.33)+(0.10 \times 0.66)+(0.10 \times 1)+(0.05 \times 0.66)=0.7$

$\mathrm{V} 3=(0.20 \times 0.75)+(0.20 \times 1)+(0.20 \times 0.75)+(0.15 \times 0.33)+(0.10 \times 0.66)+(0.10 \times 0.5)+(0.05 \times 0.66)=0.7$ $\mathrm{V} 4=(0.20 \times 0.5)+(0.20 \times 0.5)+(0.20 \times 0.5)+(0.15 \times 1)+(0.10 \times 0.33)+(0.10 \times 0.5)+(0.5 \times 1)=0.583$

Tabel 3. Hasil Perangkingan

\begin{tabular}{|c|l|c|c|}
\hline Rangking & \multicolumn{1}{|c|}{ Alternatif } & $\mathrm{V}_{\mathrm{i}}$ & Hasil Akhir (100\%) \\
\hline 1. & Sistem Pakar & 0.775 & 14.1423357664234 \\
\hline 2. & Keamanan Komputer & 0.7375 & 13.4580291970803 \\
\hline 3. & Logika Fuzzy & 0.7 & 12.7737226277372 \\
\hline 4. & Sistem Pendukung Keputusan & 0.7 & 12.7737226277372 \\
\hline 5. & Jaringan Syaraf Tiruan & 0.7 & 12.7737226277372 \\
\hline 6. & Kecerdasan Buatan & 0.675 & 12.3175182481752 \\
\hline 7. & Data Maining & 0.583 & 10.6447688564477 \\
\hline 8. & Pengolahan Citra & 0.56 & 10.3406326034063 \\
\hline 9. & Rekayasa Perangkat Lunak & 0.39 & 7.14720194647202 \\
\hline 10 & Model Simulasi & 0.35 & 6.38686131386861 \\
\hline
\end{tabular}


Implementasi sistem merupakan bagian yang menerangkan tentang penerapan dan hasil dari sistem pendukung keputusan yang dijelaskan secara satu persatu. Dimulai dari form login, menu utama, menu data dan terakhir menu laporan. Pada awal aplikasi dijalankan akan menampilkan form login, user diwajibkan untuk mengisi user name dan password yang sudah terdaftar sebelumnya. Dan akan menampilkan pesan atau peringatan (warning) jika user id atau password salah.

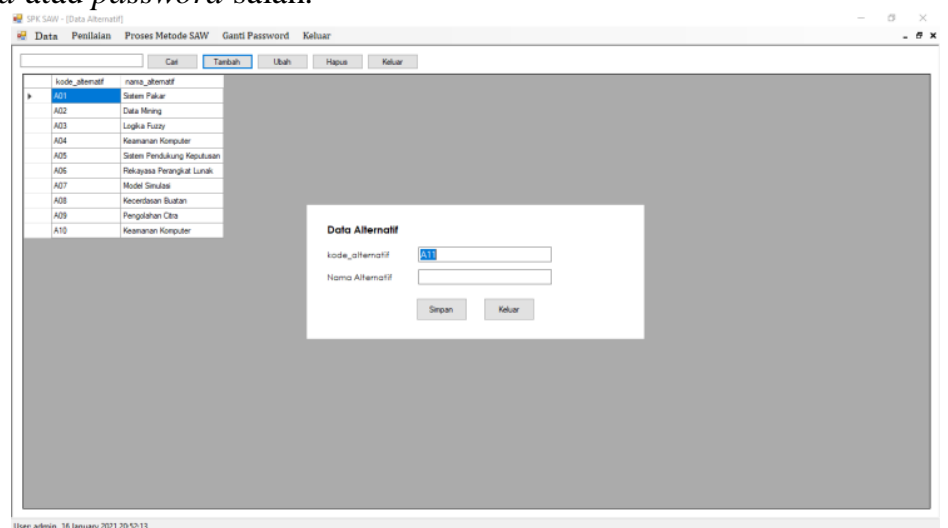

Gambar 1. Tampilan Form Menu Alternatif

Tampilan Data Kriteria ini berisikan tentang data kriteria yang akan dihitung dengan metode SAW. Adapun cara penggunaannya dengan terlebih dahulu memilih alternatif yang akan diisi nilainya, lalu isi nilai tiap kriteria, Gambar 2.

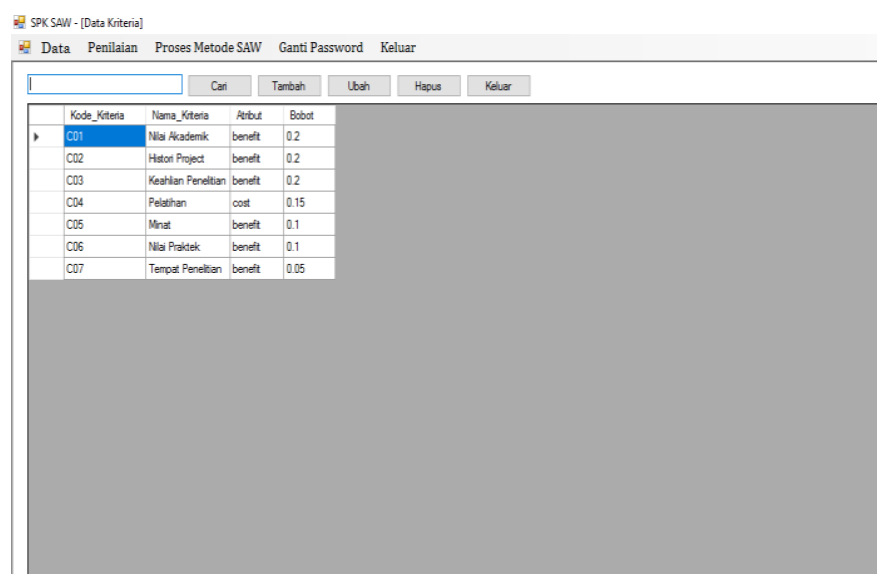

Gambar 2. Tampilan Form Menu Kriteria

Form Nilai Bobot, tampilan Nilai Bobot ini berisikan tentang data nilai bobot Bobot tiap kriteria yang akan jadi dasar perhitungan dengan metode SAW (Gambar 3). Tampilan form perhitungan metode SAW ini berfungsi untuk mengisi nilai kriteria tiap Alternatif kemudian melakukan proses perhitungan nilai criteria tersebut dan menampilkan hasil penilaian. Adapun hasil perhitungannya tampil dalam bentuk list view. Klik tombol Proses untuk memulai perhitungan dengan metode SAW, setelah itu klik tombol Cetak untuk melihat dalam bentuk laporan (Gambar 4). 


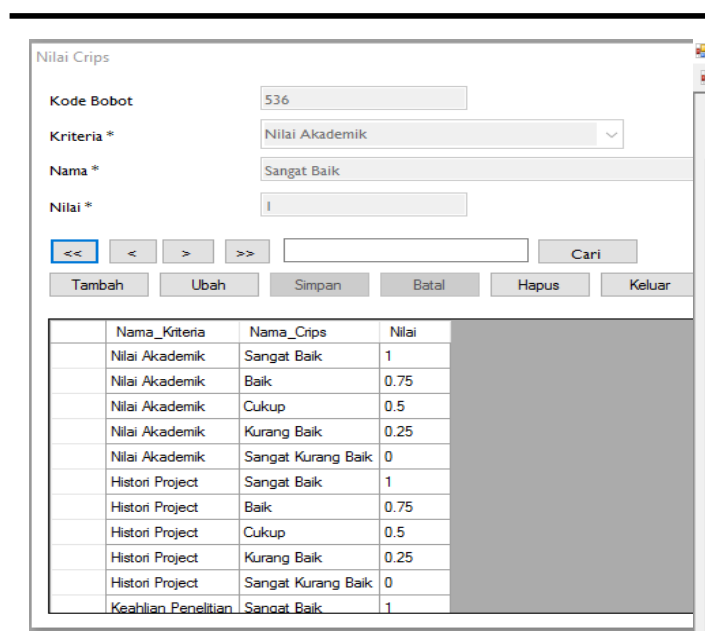

Gambar 3. Tampilan Form Nilai Bobot

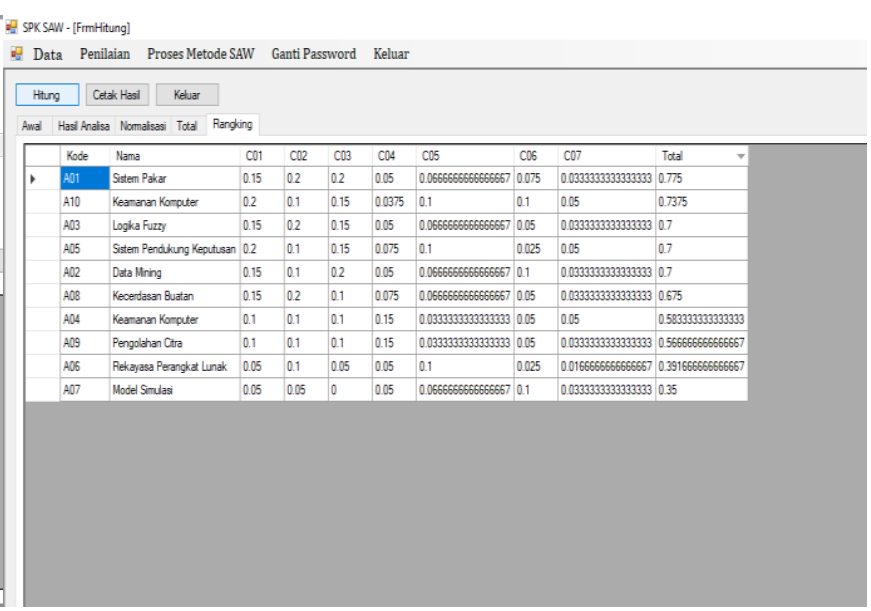

Gambar 4. Tampilan Form Perhitungan Metode SAW

\section{Kesimpulan}

Kesimpulan penelitian :

1. Sistem yang dibuat mampu menghasilkan alternatif yang dapat digunakan sebagai bahan pertimbangan mahasiswa dengan metode SAW yang performanya merupakan salah satu yang tercepat dibandingkan dengan algoritma lain.

2. Sistem dirancang dengan tampilan user friendly sehingga mudah digunakan.

6. Daftar Pustaka

[1] R. R. P. F. M. Dwi Purnomo, "Sistem Pendukung Keputusan Untuk Menentukan Judul Skripsi Jurusan Teknik Informatika Menggunakan Metode Topsis," J I M P - J. Inform. Merdeka Pasuruan, vol. 2, no. 1, pp. 16-27, 2017.

[2] L. Lisnawaty, F. Dina, and D. O. Sihombing, "Sistem Pendukung Keputusan Pemilihan Calon Tenaga Kerja di Kota Pontianak Dengan Metode Simple Additive Weighting (SAW)," J. Pilar Nusa Mandiri, vol. 14, no. 2, pp. 201-208, 2018.

[3] Y. Kurnia, A. S. Sitio, and A. S. Sinaga, "Penilaian Kinerja Guru Menggunakan Metode Topsis," JSAI (Journal Sci. Appl. Informatics), vol. 1, no. 3, pp. 70-75, 2018.

[4] Nurul Putri Utami, Hasanul Fahmi, and Anita Sindar, "Spk Penentuan Pemberian Pinjaman Kepada Anggota Bumdes Dengan Metode Simple Additive Weighting," SINTECH (Science Inf. Technol. J., vol. 2, no. 2, pp. 124-130, 2019.

[5] H. Fadli and A. Khumaidi, "Model Pengambilan Keputusan Penerima Bantuan Bedah Rumah Dinas Sosial Kabupaten Pringsewu Menggunakan Metode Saw," Prociding Kmsi, vol. 6, no. 1, pp. 164-168, 2018.

[6] A. Amiruddin, "Sistem Pendukung Keputusan Pemberian Dana Pengembangan Usaha Agribisnis Pedesaan (Puap) Kepada Gapoktan Menggunakan Metode Simple Additive Weighting (Saw)," Ilk. J. Ilm., vol. 8, no. 3, pp. 153-159, 2016.

[7] N. Evy Sophia, Indah Mumpuni, "Pendahuluan Metode Promethee SPK Sistem Pendukung Keputusan," J. Ilm. Komputasi, vol. 19, no. 2, pp. 265-278, 2020.

[8] N. Indriyani, E. Ali, U. Rio, and R. Rahmaddeni, "Menentukan Kualitas Pelayanan Maskapai Penerbangan Domestik Dengan Menggunakan Metode Naïve Bayes," SATIN-Sains dan Teknol. Inf., vol. 6, no. 1, pp. 37-44, 2020.

[9] I. Romli, "Sistem Pendukung Keputusan Dalam Penilaian Terhadap Guru Teladan Menggunakan Metode SAW Decision Support System in Assessment of Model Teacher Using SAW Method," pp. 4$5,2019$.

[10] M. Mentari and R. Wahyu, "Sistem Pendukung Keputusan Guru Berprestasi Berbasis Java Desktop Dengan Penggabungan Metode SAW dan Topsis," vol. 2, no. 2, pp. 112-122, 2020.

[11] F. Laila and A. Sindar, "Penentuan Supplier Bahan Baku Restaurant XO Suki Menggunakan Metode Weight Product," vol. 2, no. April, pp. 1-4, 2019.

[12] A. Indrawati and S. Kom, "Rancang Bangun Implementasi Sistem Metode Saw Pada Smk Al Hidayah 1 Jakarta," vol. 3, pp. 1412-1418, 2020. 